\title{
Two unknown species of Mollusca Gastropoda from the Archipelago Fernando de Noronha (Brazil), with description of a new species belonging to the genus Phidiana Gray, 1850 and a new record of Dendrodoris senegalensis Bouchet, 1975 *
}

\author{
FRANCISCO J. GARCÍA ${ }^{1}$ and JESÚS S. TRONCOSO ${ }^{2}$ \\ ${ }^{1}$ Depto. Fisiología y Zoología, Facultad Biología, Universidad Sevilla, Avda. Reina Mercedes, 6, Apdo. 1095, \\ 41080 Sevilla, Spain.E-mail: fjgarcia@us.es \\ ${ }^{2}$ Area de Biología Animal, Facultad Ciencias del Mar, Universidad Vigo, Lagoas-Marcosende, Vigo, Spain.
}

\begin{abstract}
SUMMARY: The Brazilian Archipelago of Fernando de Noronha lies off Cape Sao Roque, State of Rio Grande do Norte, about 195 nautical miles offshore. Only a few faunistic lists of this tropical archipelago have been published, and only four species of Gastropoda Opisthobranchia were cited. In this paper two species of Opisthobranchia Nudibranchia are recorded from this Archipelago. Dendrodoris senegalensis Bouchet 1975, known from Cape Verde and Senegal, amplifies its extension range toward the Western Atlantic. The brazilian specimens differ from the African specimens, in the presence of a completely white branchial tuft. Phidiana riosi sp nov clearly differs from other co-generic species in its colour pattern, having a red ground colour, with numerous white spots scattered on the dorsum. The rhinophores are orange and the cerata white with the cnidosac orange. Internally, this species has jaws with a single row of denticles, and the radular teeth have a central cusp with 7-8 denticles each side. The penis is armed with a black spine and the seminal receptacle connects with two independent ducts, the oviduct and the vaginal duct. Both species are compared with other similar taxa.
\end{abstract}

Key words: Gastropoda, Opisthobranchia, Phidiana riosi sp. nov., Dendrodoris senegalensis, Brazil, Archipelago Fernando de Noronha, taxonomy.

RESUMEN: Dos especies desconocidas de Moluscos Gasterópodos del Archipiélago Fernando de Noronha (BRASIL), CON DESCRIPCIÓN DE UNA ESPECIE NUEVA DEL GÉNERo PHIDIANA GRAY, 1850 Y NUEVOS DATOS DE DENDRODORIS SENEGALENSIS BOUCHET, 1975. - El archipiélago de Fernando de Noronha se encuentra aproximadamente a 195 millas náuticas del Cabo Sao Roque, Estado de Rio Grande do Norte. De este archipiélago se han publicado escasos listados faunísticos, en los cuales sólo se han citado cuatro especies de Gasterópodos Opistobranquios. En el presente artículo, se estudian dos especies de Opistobranquios Nudibranquios, capturados en dicho archipiélago. La especie Dendrodoris senegalensis Bouchet, 1975, conocida de Cabo Verde y Senegal, amplía su rango de distribución hacia el Oeste. Los ejemplares brasileños difieren de los africanos por la presencia de un penacho branquial completamente blanco. Phidiana riosi sp. nov. difiere claramente de otras especies del género Phidiana por su modelo cromático, con una coloración general roja, con numerosas manchas pequeñas de color blanco dispuestas por el dorso. Los rinóforos son naranja y los cerata son blancos con la región del cnidosaco naranja. Internamente, esta especie tiene las mandíbulas provistas de una sola fila de dentículos; los dientes radulares tienen una cúspide central y 7-8 dentículos en cada lado. El pene está armado con una espina negra, mientras que desde el receptáculo seminal parten dos conductos independientes, el oviducto y el conducto vaginal.

Palabras clave: Gastropoda, Opisthobranchia, Phidiana riosi sp. nov., Dendrodoris senegalensis, Brasil, Archipiélago Fernando de Noronha, taxonomía.

*Received January 9, 2002. Accepted September 19, 2002. 


\section{INTRODUCTION}

The Brazilian Archipelago of Fernando de Noronha lies off Cape Sao Roque, State of Rio Grande do Norte, about 195 nautical miles offshore (Fig. 1). It is composed of several islands of volcanic origin, lying in the north branch of the South Equatorial Current. This Archipelago was used as a Brazilian prison, but is preserved as a National Park. The islands are composed mostly of hard substrate with only a few sandy beaches, dominated by Sargassum and calcareous algae bottoms. The marine fauna of the archipelago is poorly known. Only a few taxonomic lists have been published (Laborel, 1969; Matthews and Kempf, 1970; Fausto Filho, 1974; Eston et al., 1986). In 1970, Matthews and Kempf revised the mollusc fauna from Atol das Rocas and Fernando de Noronha, and listed 77 and 168 species of molluscs respectively. However, only four species of gastropod opisthobranchs were cited: Micromelo undata (Bruguière, 1792), Hydatina vesicaria (Solander, 1786), Retusa canaliculata (Say, 1827) and Cylichna noronhensis Watson, 1883.

Two previously unrecorded species of nudibranchs were collected during the accomplishment of the project "Moluscos do Parque Nacional Marinho de Fernando de Noronha" (reference IBAMA licença 070/99), organised by Prof. Ricardo S. Absalão, from the Department of Zoology of the Federal University of Rio de Janeiro (Brazil). One of them was identified as Dendrodoris senegalensis Bouchet, 1975 and the second belongs to an undescribed species of Phidiana.

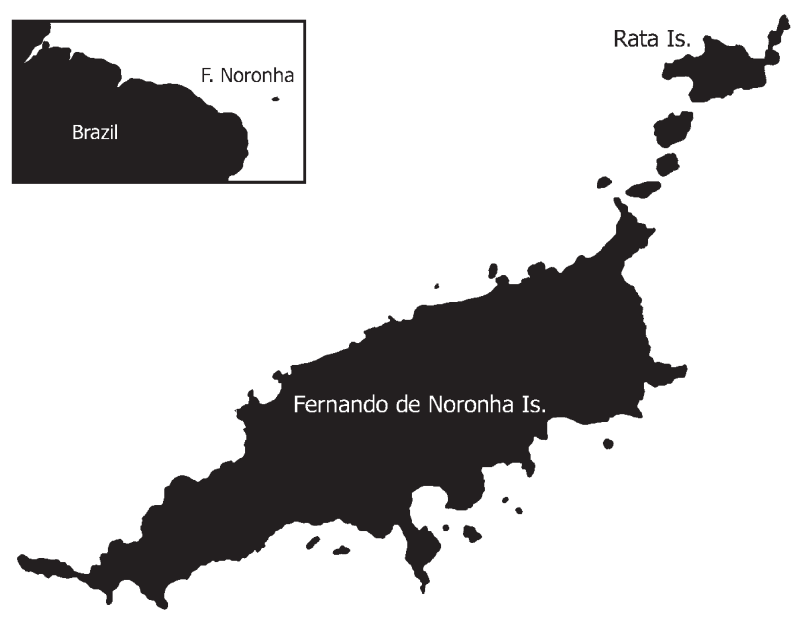

FIG. 1. - Map of Archipelago Fernando de Noronha.

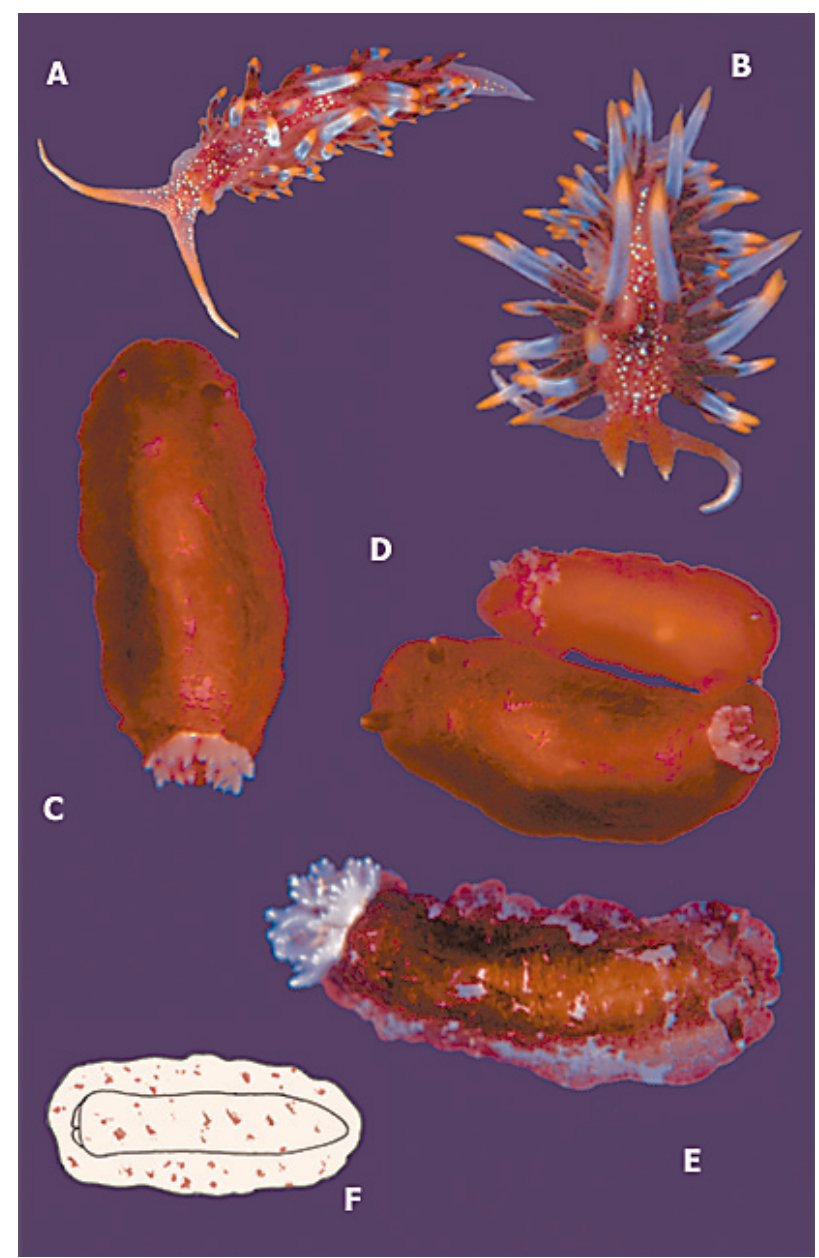

FIg. 2. - A. Phidiana riosi, specimen $15 \mathrm{~mm}$ (Holotype). B. Phidiana riosi, animal disturbed. C. Dendrodoris senegalensis, specimen $14 \mathrm{~mm}$. D. Dendrodoris senegalensis, specimens 9 and $14 \mathrm{~mm}$. E Dendrodoris senegalensis, specimen $21 \mathrm{~mm}$. F. Dendrodoris senegalensis, ventral view.

\section{RESULTS}

Phidiana riosi sp. nov.

(Figs. 2A, B, 3-6)

Material examined: Holotype, one specimen of $15 \mathrm{~mm}$ in length, collected at $14 \mathrm{~m}$ depth at Rata Island (17/06/2000), deposited at the Museu Oceanográfico "Prof. Eliézer de Carvalho Rios" from the Foundation University of Rio Grande, in Rio Grande, Brazil, with the registration number 42.010. Paratypes, two specimens, 16 and $18 \mathrm{~mm}$ in length, collected at $12 \mathrm{~m}$ depth at the same station $(18 / 06 / 2000)$, are deposited in the Museo Nacional de Ciencias Naturales de Madrid (Spain) with the registration number MNCN $15.05 / 44363$.

Other material: Three specimens, 11,16 and $17 \mathrm{~mm}$ in length, collected at $14 \mathrm{~m}$ depth at Rata Island (17/06/2000). These specimens were used for dissection.

Etymology: The name riosi was chosen in honor of Dr. Eliézer de Carvalho Rios, a Brazilian malacologist and friend. 

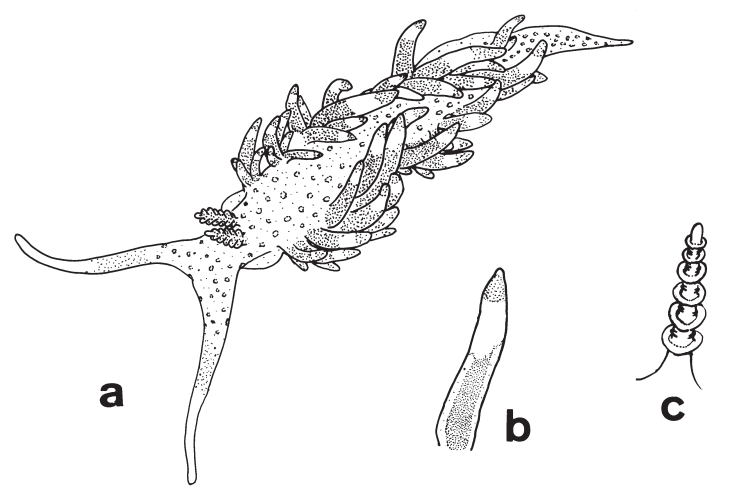

FIG. 3. - Phidiana riosi, A, dorsal view of an animal. B, detail of a cera. $\mathrm{C}$, detail of the rhinophore.

A

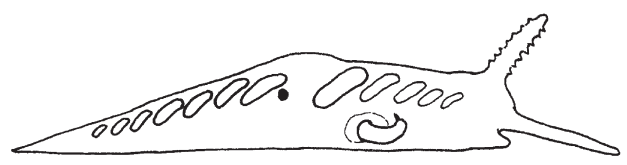

B

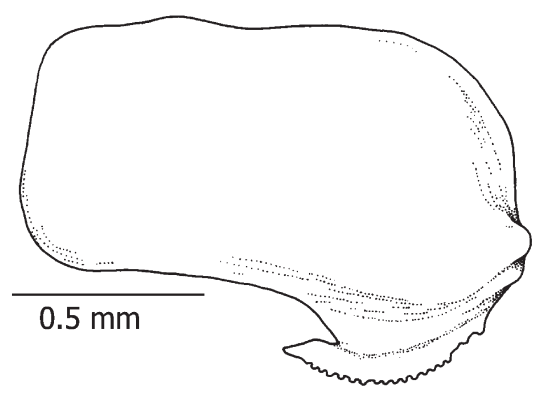

C

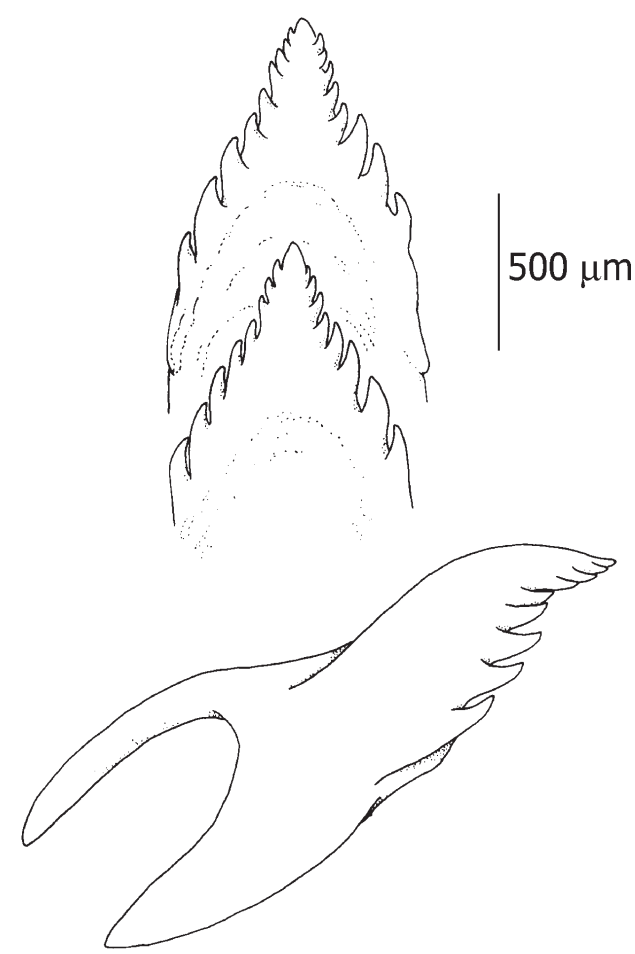

FIG. 4. - Phidiana riosi, A, diagrammatic right profile showing the insertion of the cerata. B, jaw. C, radular teeth.
External anatomy (Figs. 2A, B; 3, 4A): The body is elongated; length between 11 and $18 \mathrm{~mm}$. The oral tentacles are long $(3.2-5 \mathrm{~mm})$ and cylindrical. The rhinophores are slightly shorter than the oral tentacles, having 6-7 large annulations and 6-7 shorter annulations intercalated between them. The eyes lie behind the base of the rhinophores.

The cerata are cylindrical and the cnidosac is pointed. The precardiac cerata are arranged in five oblique rows and the postcardiac ceratal clusters are arranged in seven oblique rows, having one ceratal row per branch of the posterior liver duct. The outer cerata of the rows are shorter than the inner ones. The number of cerata per cluster in the $17 \mathrm{~mm} \mathrm{spec-}$ imen is: precardiac rows with $3,5,7,8$ and 7 cerata respectively on the right side and 5, 4, 7, 7 and 7 cerata respectively on the left side. The postcardiac rows with $3,6,5,3,3,2$ and 2 cerata respectively on the right side and 7, 5, 6, 3, 4, 2 and 2 cerata respectively on the left side. The genital papilla is situated on the right side of the body, below the fourth precardiac ceratal row. The anus opens between the last precardiac ceratal row and the first postcardiac row. The foot is narrow and the propodial tentacles are absent.

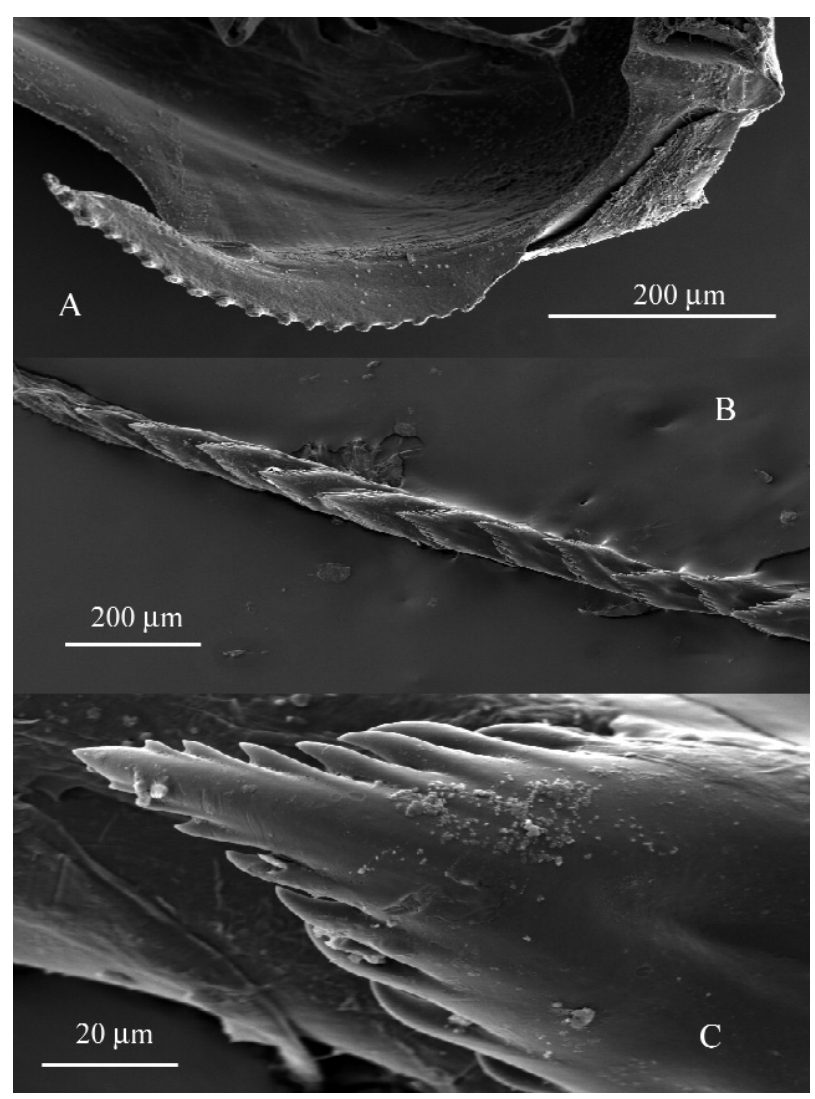

FIG. 5. - Phidiana riosi, A. SEM photograph of jaw cutting border. $B, C$, SEM photographs of the radula. 
When the animals are disturbed, the rhinophores are directed forward, the body is slightly curved and the cerata are straight, showing a symmetrical disposition along the animal. The innermost cera of some ceratal rows become erect, while the others stand out horizontally (Fig. 2B).

Coloration (Figs. 2A, B, 3): The ground colour is reddish with numerous white spots on the dorsal and lateral surfaces of the body. The basal third of the oral tentacles is reddish with white spots, the middle third is orange and the apical third is hyaline white. The foot is reddish. The rhinophores are orange with a white tip. The cerata have the surface of cnidosac area orange; the subapical area of the cerata are white with a translucent basal third. Dark brown digestive gland branches are visible through the translucent tissue.
Internal anatomy: The jaws are colourless, ovate and convex on the outer surface. The masticatory border has a single row with 17 rounded denticles in a specimen of $17 \mathrm{~mm}$ in length (Figs. 4B, 5A). The radular formula of the same specimen is $13 \times 0.1 .0$. The teeth have a median cusp and 7-8 hooked denticles on either side. Outer denticles are bigger than median denticles (Figs. 4C, 5B,C).

Reproductive system (Fig. 6). The hermaphroditic duct widens into a convoluted ampulla, which divides into an oviduct and a short deferent duct. The oviduct connects separately with an ovoid seminal receptacle. The distal end of the vaginal duct connects with the seminal receptacle next to the oviduct. The deferent duct lacks a morphological differentiated prostate. The penis is cylindrical and armed with a pointed apical black spine.

Table 1.- Comparative table of Phidiana species.

\begin{tabular}{|c|c|c|c|c|c|c|}
\hline & P. riosi & $\begin{array}{l}\text { P.pegasus } \\
\text { Willan } 1987\end{array}$ & $\begin{array}{c}\text { P. milleri } \\
\text { Rudman } 1980\end{array}$ & $\begin{array}{c}P . \text { militaris } \\
\text { (Alder \& Hancock 1864) }\end{array}$ & $\begin{array}{c}\text { P. bourailli } \\
\text { (Risbec, 1928) }\end{array}$ & $\begin{array}{l}\text { P. salaamica } \\
\text { Rudman } 1980\end{array}$ \\
\hline References & present paper & Willan 1987 & $\begin{array}{l}\text { Miller, 1974; } \\
\text { Rudman 1980; } \\
\text { Willan 1987 }\end{array}$ & $\begin{array}{l}\text { Gosliner 1979; } \\
\text { Rudman } 1980\end{array}$ & $\begin{array}{l}\text { Rudman 1980; } \\
\text { Marshall \& Willan } 1999\end{array}$ & Rudman 1980 \\
\hline Locality & $\begin{array}{l}\text { Fernando de Noronha } \\
\text { (Brazil) }\end{array}$ & New Zealand & New Zealand, India & $\begin{array}{l}\text { India, Japan, } \\
\text { New Caledonia }\end{array}$ & $\begin{array}{l}\text { Australia, } \\
\text { Tanzania }\end{array}$ & Tanzania \\
\hline Length & $18 \mathrm{~mm}$ & $22 \mathrm{~mm}$ & $42 \mathrm{~mm}$ & $35 \mathrm{~mm}$ & $18 \mathrm{~mm}$ & $13 \mathrm{~mm}$ \\
\hline Tentacular foot & absent & present & present & present & present & present \\
\hline Oral tentacles & $\begin{array}{l}1 / 4 \text { the body } \\
\text { length }\end{array}$ & $\begin{array}{l}1 / 3 \text { the body } \\
\text { length }\end{array}$ & $\begin{array}{l}\text { 1/3-1/6 the body } \\
\text { length }\end{array}$ & $\begin{array}{l}1 / 6 \text { the body } \\
\text { length }\end{array}$ & $\begin{array}{l}\text { longer than } \\
\text { rhinophores }\end{array}$ & $\begin{array}{l}\text { similar than } \\
\text { rhinophores }\end{array}$ \\
\hline Rhinophores & $\begin{array}{l}\text { 6-7 complete lamellae } \\
\text { and 6-7 intercalated } \\
\text { small lamellae }\end{array}$ & $\begin{array}{l}\text { with low } \\
\text { pustules }\end{array}$ & $\begin{array}{l}\text { smooth, sometimes } \\
\text { with wrinkled } \\
\text { bases }\end{array}$ & $\begin{array}{l}\text { smooth, distinctly } \\
\text { inflated in the } \\
\text { central region }\end{array}$ & 3-5 large complete flanges & smooth \\
\hline Anus & $\begin{array}{l}\text { below the } 1 \text { st } \\
\text { postcardiac ceratal } \\
\text { row }\end{array}$ & $\begin{array}{l}\text { between } 2 \text { nd and } \\
\text { 3rd ceras in } \\
\text { ninth row }\end{array}$ & $\begin{array}{c}\text { between the lower } \\
\text { cerata of } 4 \text { row in the } \\
\text { 1st post-pericardial cluster }\end{array}$ & $\begin{array}{l}\text { base of the anterior } \\
\text { rows of the } 2 \text { nd } \\
\text { cluster }\end{array}$ & $\begin{array}{l}\text { base of } 3 \text { row of } \\
\text { the } 2 \text { nd ceratal } \\
\text { cluster }\end{array}$ & $\begin{array}{l}\text { between two central } \\
\text { rows of } 2 \text { nd } \\
\text { cluster }\end{array}$ \\
\hline Cerata & $\begin{array}{c}\text { arranged in } 12 \text { single } \\
\text { oblique rows }\end{array}$ & $\begin{array}{c}\text { arranged in } 6 \text { single, } \\
\text { parallel, oblique } \\
\text { rows }\end{array}$ & $\begin{array}{l}\text { arranged in } 6-9 \text { cluster } \\
\text { with oblique ro } \\
\text { rows. 1st cluster } \\
\text { with 6-9 rows }\end{array}$ & $\begin{array}{c}6 \text { precardial oblique } \\
\text { rows; } 5 \text { postcardial clusters } \\
\text { with } 6,4,3,4,4 \\
\text { oblique rows }\end{array}$ & $\begin{array}{c}3-4 \text { clusters widely } 9 \\
\text { spaced of } \\
\text { oblique rows }\end{array}$ & $\begin{array}{l}\text { cluster of } 2 \text { oblique } \\
\text { rows, } 1 \text { st cluster } \\
\text { with } 5 \text { rows }\end{array}$ \\
\hline Color pattern & $\begin{array}{l}\text { reddish with } \\
\text { numerous } \\
\text { white spots }\end{array}$ & $\begin{array}{l}\text { pigmentation uniform, } \\
\text { rich apricot- } \\
\text { orange }\end{array}$ & $\begin{array}{l}\text { translucent white. } \\
\text { Head deed orange. } \\
\text { Cerata deep reddish-brown } \\
\text { with white apices }\end{array}$ & $\begin{array}{l}\text { white rather than } \\
\text { translucent. } \\
\text { Head with } \\
3 \text { oranges lines }\end{array}$ & $\begin{array}{l}\text { translucent white } \\
\text { with opaque white } \\
\text { spots and thin } \\
\text { vivid vermilion lines }\end{array}$ & translucent white \\
\hline Radula & $\begin{array}{c}13 \text { teeth. } 8-9 \\
\text { sharply pointed } \\
\text { denticles on either } \\
\text { side of central cusp }\end{array}$ & $\begin{array}{l}\text { 14-17 teeth. Strong } \\
\text { median cusp and } \\
3-5 \text { denticles } \\
\text { flanking it }\end{array}$ & $\begin{array}{l}17 \text { teeth. Prominent } \\
\text { median cusp } \\
\text { flanked ut to } 5 \text { large } \\
\text { denticles on each side }\end{array}$ & $\begin{array}{l}\text { 22-24 teeth. Prominent } \\
\text { central cusp and } \\
\text { 6-8 large denticles } \\
\text { on each side }\end{array}$ & $\begin{array}{l}19 \text { teeth. Prominent } \\
\text { cusp and 5-7 } \\
\text { pointed denticles } \\
\text { on each side }\end{array}$ & 30 teeth \\
\hline $\begin{array}{l}\text { Masticatory } \\
\text { border of jaws }\end{array}$ & $\begin{array}{l}\text { a row of } 17 \text { large } \\
\text { rounded teeth }\end{array}$ & $\begin{array}{l}\text { a row of } 12-15 \\
\text { rounded denticles }\end{array}$ & $\begin{array}{l}\text { a row of large } \\
\text { rounded denticles }\end{array}$ & $\begin{array}{l}\text { a row of about } 20 \\
\text { large rounded denticles }\end{array}$ & $\begin{array}{l}\text { a row of spaced } \\
\text { rounded denticles }\end{array}$ & $\begin{array}{l}\text { a row of spaced } \\
\text { rounded denticles }\end{array}$ \\
\hline \multicolumn{2}{|c|}{$\begin{array}{l}\text { Connection of vagina } \\
\text { and oviduct to double } \\
\text { seminal receptacle }\end{array}$} & single & single & single & - & single \\
\hline Penial stylet & present & absent & absent & absent & $\begin{array}{c}\text { basal region with } \\
\text { semicircular structure } \\
\text { bearing a row of warts, } \\
\text { each surmounted by a } \\
\text { chitinous spine }\end{array}$ & $\begin{array}{l}\text { penial papilla with a } \\
\text { sharply angled ridge } \\
\text { up one side bearing } \\
\text { small chitinous } \\
\text { projections }\end{array}$ \\
\hline
\end{tabular}




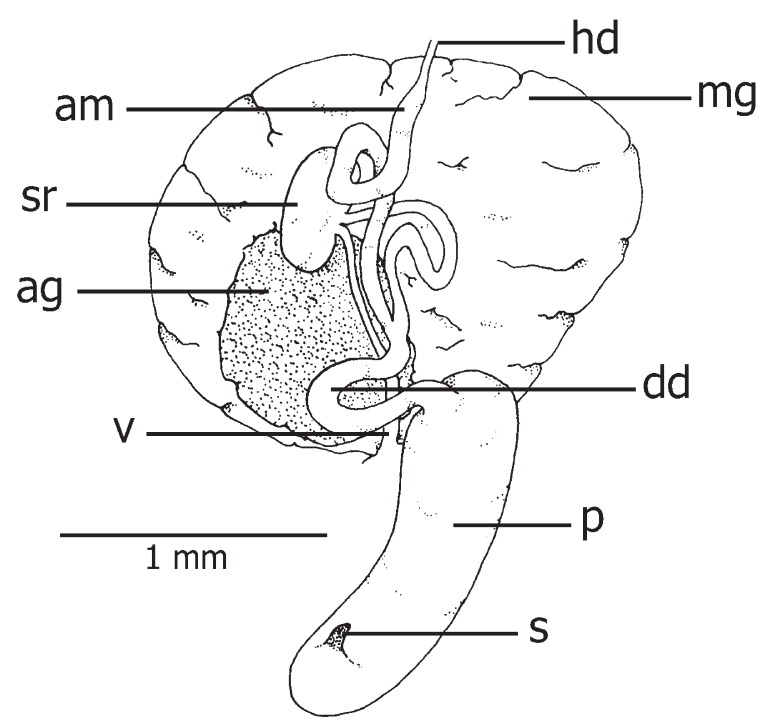

FIG. 6. - Phidiana riosi. Reproductive system. ag, albumen gland; am, ampulla; dd, deferent duct; hd, hermaphroditic duct; mg, mucous gland; p, penis; s, spine; sr, seminal receptacle; v, vagina.
Remarks: This species belongs to the genus Phidiana because it has long oral tentacles, the rhinophores are lamellate, the foot is anteriorly rounded, all the ceratal clusters are disposed in oblique rows, the jaws have a masticatory border with a row of denticles, the radular teeth are provided with lateral denticles on a central cusp and the penis is armed with a spine. A comparative table of Phidiana species is presented in Table 1. Only one species of Phidiana has been described from Brazilian coasts, P. lynceus Bergh, 1867, which differs clearly from our specimens in the colour pattern; P. lynceus has a white line running mid-dorsally which branches up the basal parts of the oral tentacles, and orange bands on the rhinophores and oral tentacles. Furthermore, there are several ceratal rows from each branch of the posterior liver duct, while there is only one row per branch in $P$. riosi. Finally, in the reproductive sys-

Table 1 (Cont.).- Comparative table of Phidiana species.

\begin{tabular}{|c|c|c|c|c|c|c|c|}
\hline & $\begin{array}{c}\text { P. hiltoni } \\
\text { (O’Donoghue, 1927) }\end{array}$ & $\begin{array}{l}\text { P. lynceus } \\
\text { Bergh } 1867\end{array}$ & $\begin{array}{c}\text { P. lascrucensis } \\
\text { Bertsch \& Ferreira } \\
1974\end{array}$ & $\begin{array}{c}\text { P. mariadelmarae } \\
\text { García \& Troncoso } \\
1999\end{array}$ & $\begin{array}{l}\text { P. newcombi } \\
\text { (Angas 1864) }\end{array}$ & $\begin{array}{l}\text { P. longicirrha } \\
\text { Eliot, } 1906\end{array}$ & $\begin{array}{c}\text { P. lottini } \\
\text { (Lesson, 1831) }\end{array}$ \\
\hline References & $\begin{array}{c}\text { Lance 1962; } \\
\text { MacFarland 1966; M } \\
\text { Roller 1972; } \\
\text { Behrens 1991 }\end{array}$ & $\begin{array}{l}\text { Edmunds 1964; } \\
\text { Marcus \& Marcus } 1967 \\
\text { Thompson } 1980\end{array}$ & $\begin{array}{l}\text { Bertsch \& Ferreira } \\
\quad 1974\end{array}$ & $\begin{array}{c}\text { García \& Troncoso } \\
1999\end{array}$ & $\begin{array}{l}\text { Burn 1957, } \\
\quad 1966\end{array}$ & Eliot 1906 & $\begin{array}{l}\text { Engel 1925; } \\
\text { Marcus } 1959\end{array}$ \\
\hline Locality & California, Mexico & Jamaica, Brazil & Mexico & Coiba Island (Panama) & Australia & Cape Verde & Peru \\
\hline Length & $63 \mathrm{~mm}$ & $18 \mathrm{~mm}$ & $22 \mathrm{~mm}$ & $17 \mathrm{~mm}$ & $15 \mathrm{~mm}$ & $9 \mathrm{~mm}$, preserved & $15-90 \mathrm{~mm}$ \\
\hline Tentacular foot & absent & present & absent & absent & present & absent & - \\
\hline Oral tentacles & $\begin{array}{l}1 / 4 \text { the body } \\
\text { length }\end{array}$ & - & $\begin{array}{l}1 / 4-1 / 3 \text { the } \\
\text { body length }\end{array}$ & $\begin{array}{l}\text { longer } \\
\text { than rhinophores }\end{array}$ & - & $\begin{array}{l}\text { longer than } \\
\text { rhinophores }\end{array}$ & - \\
\hline Rhinophores & $\begin{array}{l}11 \text { complete folds, } \\
11 \text { intercalated } \\
\text { on posterior side }\end{array}$ & $\begin{array}{l}\text { annulations } \\
\text { rarely complete } \\
\text { anteriorly }\end{array}$ & $\begin{array}{l}15 \text { complete } \\
\text { annulations }\end{array}$ & $\begin{array}{l}\text { basal third smooth, } \\
2 \text { apical thirds } \\
\text { with } 12 \text { annulations }\end{array}$ & $\begin{array}{c}4 \text { encircling } \\
\text { rings of nodular } \\
\text { papillae }\end{array}$ & perfoliated & perfoliated \\
\hline Anus & $\begin{array}{l}\text { below the middle } \\
\text { of } 2 \text { nd group }\end{array}$ & $\begin{array}{c}\text { between } 3 \text { rd and } 4 \text { th } \\
\text { postcardial row }\end{array}$ & $\begin{array}{c}\text { about the middle } \\
\text { of the } 2 \text { nd } \\
\text { cerata group }\end{array}$ & - & - & - & - \\
\hline Cerata & $\begin{array}{c}10 \text { precardial } \\
\text { oblique rows and } \\
20 \text { postcardial } \\
\text { oblique rows }\end{array}$ & in rows & $\begin{array}{l}\text { two group of } \\
6-9 \text { and } 8-15 \\
\text { ceratal rows }\end{array}$ & $\begin{array}{l}2 \text { groups of } 7 \\
\text { and } 8 \text { oblique } \\
\text { rows }\end{array}$ & $\begin{array}{c}\text { 4-5 groups, } \\
\text { first } 2 \text { groups set } \\
\text { on horseshoe, rest } \\
\text { on oblique rows }\end{array}$ & $\begin{array}{l}\text { cerata perfoliated } \\
\text { and disposed } \\
\text { in } 2 \text { set of rows }\end{array}$ & 20-26 rows \\
\hline Color pattern & $\begin{array}{l}\text { translucent white; } \\
\text { orange line along } \\
\text { anterior side of } \\
\text { the head and basal } \\
\text { fourth of oral tentacles }\end{array}$ & $\begin{array}{l}\text { silvery-grey; } \\
\text { head suffused } \\
\text { with orange }\end{array}$ & $\begin{array}{l}\text { orangish } \\
\text { with numerous } \\
\text { white specks }\end{array}$ & $\begin{array}{l}\text { orange, white } \\
\text { middorsal line } \\
\text { extending to the } \\
\text { apex of the oral } \\
\text { tentacles }\end{array}$ & $\begin{array}{l}\text { body colour pale } \\
\text { green maculated } \\
\text { with cream }\end{array}$ & $\begin{array}{l}\text { white translucent } \\
\text { with white } \\
\text { specks }\end{array}$ & $\begin{array}{l}\text { grey whitish, or } \\
\text { reddish, with } 2 \\
\text { white spots anterior } \\
\text { and posterior to } \\
\text { rhinophores }\end{array}$ \\
\hline Radula & $\begin{array}{l}21 \text { teeth. 4-6 } \\
\text { large denticles on } \\
\text { lower margin of } \\
\text { the teeth, central cusp } \\
\text { with } 3-4 \text { smaller denticles }\end{array}$ & $\begin{array}{l}14 \text { teeth. A central } \\
\text { cusp and } 8-10 \\
\text { lateral denticles } \\
\text { es }\end{array}$ & $\begin{array}{l}15 \text { teeth. A central } \\
\text { cusp and } 8-10 \\
\text { lateral denticles }\end{array}$ & 20 teeth & $\begin{array}{l}\text { prominent central } \\
\text { cusp. 4-5 lateral } \\
\text { denticles }\end{array}$ & $\begin{array}{l}\text { strong central } \\
\text { cusp, 4-5 lateral } \\
\text { denticles }\end{array}$ & $\begin{array}{l}\text { teeth with } \\
6 \text { lateral } \\
\text { denticles }\end{array}$ \\
\hline $\begin{array}{l}\text { Masticatory } \\
\text { border of jaws }\end{array}$ & $\begin{array}{l}25-30 \text { irregular } \\
\text { blunt denticles }\end{array}$ & with 18 denticles & $\begin{array}{l}2 \text { rows of } \\
\text { denticles }\end{array}$ & $\begin{array}{l}\text { a row with } 15-22 \\
\text { hooked denticles }\end{array}$ & - & $\begin{array}{l}\text { a row of large } \\
\text { denticles }\end{array}$ & $\begin{array}{l}\text { a row of } \\
\text { denticles }\end{array}$ \\
\hline $\begin{array}{l}\text { Connection of } \\
\text { and oviduct to } \\
\text { seminal recepta }\end{array}$ & $\begin{array}{l}\text { vagina } \\
\text { acle }\end{array}$ & single & - & single & - & - & - \\
\hline Penial stylet & present & present & present & present & - & absent & present \\
\hline
\end{tabular}


tem of $P$. riosi the seminal receptacle is serial with two independent ducts (oviduct and vaginal duct), while there is only one duct in P. lynceus.

Other species of Phidiana with reddish or orange colour are P. lottini (Lesson, 1831), P. lascrucensis Bertsch and Ferreira 1974 and P. mariadelmarae García and Troncoso 1999, all of them from Pacific Ocean. P. lottini is grey whitish, some times reddish, having two white spots lying anterior and posteriorly to the rhinophores; the cerata are organized in 2026 rows and the radular teeth only have 6 lateral denticles (Engel, 1925; Marcus, 1959, cited as $P$. inca). P. lascrucensis is orangish to orange-yellow with numerous white specks scattered randomly along the dorsum, and the jaws are characterised by the presence of a masticatory border with two rows of denticles (Bertsch and Ferreira, 1974). P. mariadelmarae is orange having a middorsal longitudinal white line that bifurcates at the base of the rhinophores, and only one duct joining the seminal receptacle in the reproductive system (García and Troncoso, 1999).

In warm western Atlantic waters, fourteen facelinid species have been described. Among them, only Facelina coenda Marcus, 1958 has the cerata in rows (Marcus, 1958). However this species differs from $P$. riosi in the coloration and in the spines of the penis (Marcus, 1958).

Dendrodoris senegalensis Bouchet 1975 (Figs. 2 C, D, E, F, 7, 8)

Material examined: Two specimens 9 and $14 \mathrm{~mm}$ in length, collected at $14 \mathrm{~m}$ depth at Rata Island (19/06/2000). One specimen, 21 $\mathrm{mm}$ in length, collected at the intertidal zone at Fernando de Noronha Island (07/07/1999).

External anatomy (Figs. 2 C-F): The body is soft and smooth, lacking spicules. The notal margin is delicate and slightly striated. The rhinophores have a cylindrical stalk and the club is lamellate. The branchial tuft has five moderately long tripinnate gills arranged in a circle. The anal papilla lies at the centre of the branchial circle. The oral tentacles are absent.

Coloration (Figs. 2 C, D, E, F): The dorsal surface and notal margin are uniformly red except in the $21 \mathrm{~mm}$ long specimen, which is red-brown with irregular white areas (Fig. 2E). The rhinophores are red with the tip white. The gills are uniformly white. The anal papilla is uniformly white too. Ventrally, the notal margin and foot are white with small red spots (Fig. 2F).

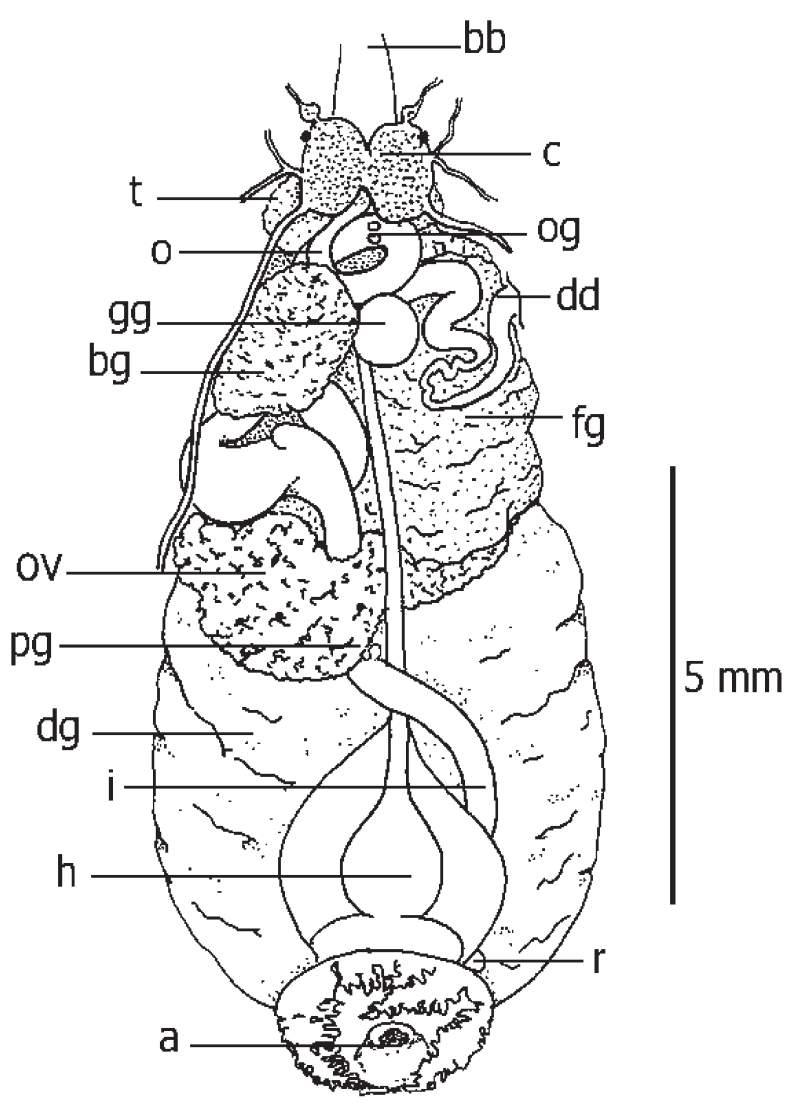

FIG. 7. - Dendrodoris senegalensis. Dorsal view of the internal organs. a, anus; bb, buccal bulb; bg, blood gland; c, central nervous system; dd, deferent duct; dg, digestive gland; fg, female gland; gg, gametolytic gland; h, heart; $\mathrm{i}$, intestine; o, oesophagus; og, oesophageal gland; ov, ovotestis; pg, pyloric gland; r, renal sac, t, ptyaline gland.

Internal anatomy: An impair ptyaline gland is connected to the buccal bulb. The oesophagus is long, with two small oesophageal glands near to the buccal bulb. The intestine has a small pyloric gland. The heart is connected through the aorta to the blood gland (Fig. 7).

The reproductive system has an ovotestis lying interdigitating on the anterior portion of the digestive gland (Figs. 7, 8). The hermaphroditic duct connects with a short and enlarged ampulla. The deferent duct has a proximal prostatic portion and a narrow and folded distal region. The male eversible cirrus has numerous hooks with slightly elongate bases. The gametolytic gland is spherical. A separate duct connects with the smaller, long stalked seminal receptacle just before it enters the female gland mass.

Remarks: On Brazilian coasts only one species of Dendrodoris has been described, D. krebsii (Mörch, 1863) (Marcus, 1977; Rios, 1994; Valdés et 

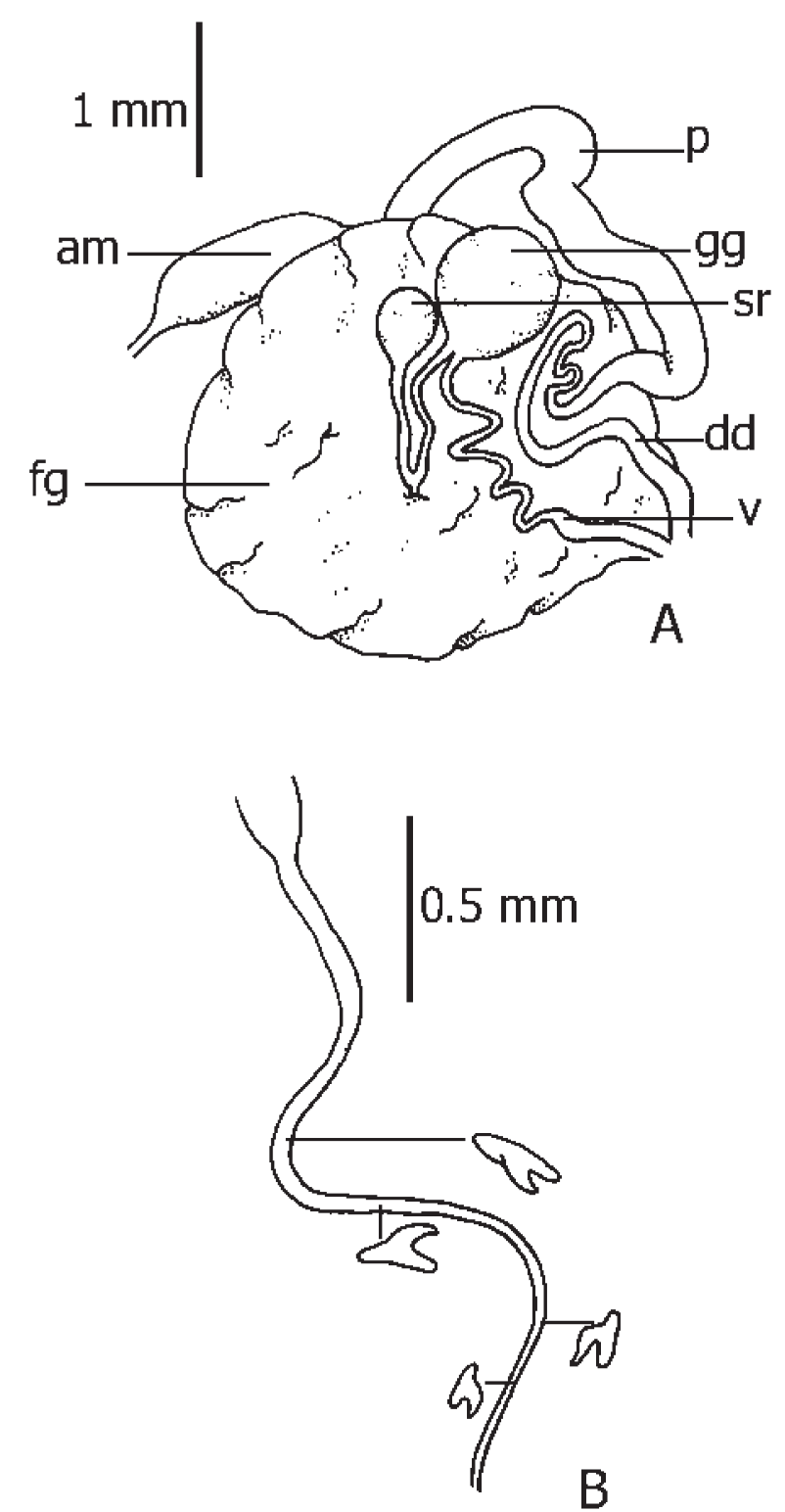

FIG. 8. - Dendrodoris senegalensis. A. Reproductive system. B. Hooks along the male eversible cirrus. am, ampulla; dd, deferent duct; fg, female gland; gg, gametolytic gland; p, prostatic duct; sr, seminal receptacle; $v$, vagina.

al., 1996), which differs from our specimens in the coloration; besides this, the notal margin is clearly wider in $D$. krebsii, the blood gland is larger and the reproductive system of $D$. krebsii has the ampulla with a fold, and the length of it and the prostate are greater than those of our specimens. Finally, the male cirrus of our specimens has hooks with very short bases, whereas they are large in D. krebsii (Valdés et al., 1996).

D. senegalensis is known from Cape Verde and Senegal, on the east coast of Africa (Bouchet, 1975; Valdés et al, 1996). The real geographic range of this species is unknown, owning to the lack of sam- pling effort in this part of the World. Our specimens differ from those from Africa in the coloration of the gills. Bouchet (1975) and Valdés et al (1996) stated that the gills of $D$. senegalensis have the same coloration as the dorsum, having the external border white; however in the Brazilian specimens the gills and anal papilla are uniformly white, clearly different from the dorsum, which is red or red brown with white irregular spots. Internally, our specimens coincide with the descriptions of $D$. senegalensis by Bouchet (1975) and Valdés et al. (1996).

As stated above, the Fernando de Noronha Archipelago lies in the north branch of the South Equatorial Current. It is possible that larvae are able to cross the Atlantic Ocean in this area, which is the narrowest point, following the ocean currents. As the only consistent difference of our specimens is the presence of a white gill, and coloration is extremely variable in species of Dendrodoris, we consider that our specimen belongs to the species $D$. senegalensis, providing a considerable range extension for this taxon.

\section{ACKNOWLEDGEMENTS}

We wish to express our gratitude to Laboratorio de Malacologia, Depto. Zoologia, Univ. Federal Rio Janeiro Brazil for their assistance, to Dr. Ricardo S. Absalão and Dr. Paulo M. Costa for their constant help, and to Angel Valdés for his comments. This research was included in the project "Moluscos do Parque Nacional Marinho de Fernando de Noronha" with the reference IBAMA licença 070/99 and financed by a project supported by Agencia Española de Cooperación Internacional (AECI) and Ministerio de Educación y Cultura from Spain.

This paper has been partially supported by the project PHB2002-0045-PC of the Dirección General de Universidades del Ministerio de Educación, Cultura y Deportes of Spain.

\section{REFERENCES}

Behrens, D.W. - 1991. Pacific coast nudibranchs. Sea Challenger, Monterey, California.

Bertsch, H. and A.J. Ferreira. - 1974. Four new species of Nudibranchs from Tropical West America. Veliger, 16: 343-353.

Burn, R.F. - 1966. Port Philip Survey 1957-1963. Opisthobranchia. Mem. Nat. Mus. Vict., 27: 265-288.

Bouchet, Ph. - 1975. Nudibranches nouveaux des côtes du Senegal. Vie Milieu, 25(1 A): 119-132.

Edmunds, M. - 1964. Eolid mollusca from Jamaica, with descriptions of two new genera and three new species. Bull. mar. Sci. Guf Caribb., 14(1): 1-32. 
Engel, H. - 1925. Westindische Opisthobranchiate Mollusken I. Aeolidiadae, Thesis, University of Amsterdam. 1-48.

Eston, U.R., A.E. Migotto, E.C. Oliveira Filho, S.A. Rodrigues and J.C. Freitas. - 1986. Vertical distribution of benthic marine organisms on rocky coast of the Fernando de Noronha Archipelago (Brazil). Bol. Inst. Ocean. S. Paulo, 34:37-53.

Fausto-Filho, J. - 1974. Stomatopod and Decapod Crustacea of the Archipelago of Fernando de Noronha, Northeast Brazil. Arq. Cien Mar., 14(1):1-35.

García, F.J. and J.S. Troncoso. - 1999. Description of a new species of the genus Phidiana Gray, 1850 (Nudibranchia: Facelinidae) from Pacific Ocean waters of Panama. Veliger, 42(2): 190-193.

Gosliner, T.M. - 1979. The systematics of the Aeolidacea (Nudibranchia: Mollusca) of the Hawaiian Islands, with descriptions of two new species. Pacific Sci., 33(1): 37-77.

Laborel, J. - 1969. Les peuplements de madréporaires de cotês tropicales du Brásil. Ann. Universite Abidjan, (E)2(3):1-260.

Lance, J.R. - 1962. Two new opisthobranch mollusks from Southern California. Veliger, 4: 155-159.

MacFarland, F.M. - 1966. Studies of opisthobranchiate molluscs of the Pacific coast of North America. Mem. Calif. Acad. Sci., 6: $1-546$.

Marcus, E. - 1958. On western Atlantic opisthobranchiate gastropods. Am. Mus. Nov., 1906: 1-82.

Marcus, E. - 1959. Lamellariacea und Opisthobranchia. Reports of the Lund University Chile Expedition 1948-49, No. 36. Lunds Univ. Arssk., 55: 1-133.

Marcus, Ev. Du B.-R. - 1977. An annotated check list of the Western Atlantic warm water Opisthobranchs. J. Moll. Stud., Suppl. 4: $1-22$.
Marcus, Ev. Du B.R. and E. Marcus. - 1967. American Opisthobranch Mollusks. Stud. trop. Oceanogr. Miami, 6: 1-256.

Marshall, J.G. and R.C. Willan. - 1999. Nudibranchs of Heron Island, great barrier reef. A survey of the Opisthobranchia (Sea Slugs) of Heron and Wistari reefs. Backhuys Publishers Leiden.

Matthews, H.R. and M. Kempf. - 1970. Moluscos marinhos do Norte e Nordeste do Brasil. II - Moluscos do Arquipélago de Fernando de Noronha (com algumas referências ao Atol das Rocas). Arq. Cien Mar., 10(1): 1-53.

Miller, M.C. - 1974. Aeolid nudibranchs (Gastropoda: Opisthobranchia) of the family Glaucidae from New Zealand waters. Zool. J. Linn. Soc., 54: 31-61.

Rios, E. - 1994. Seashells of Brazil. Editora da Fundaçao Universidade do Rio Grande: Rio Grande.

Roller, R.A. - 1972. Three new species of eolid nudibranchs from the West coast of North America. Veliger, 14(4): 416-423.

Rudman, W.B. - 1980. Aeolid opisthobranch molluscs (Glaucidae) from the Indian Ocean and the south-west Pacific. Zool. J. Linn. Soc., 68(2): 139-172.

Thompson, T.E. - 1980. Jamaican Opisthobranch Molluscs II. $J$. Moll. Stud., 46: 74-99.

Valdés, A., J. Ortea, C. Avila and M. Ballesteros. - 1996. Review of the genus Dendrodoris Ehrenberg, 1831 (Gastropoda: Nudibranchia) in the Atlantic Ocean. J. Moll. Stud, 62: 1-31.

Willan, R.C. - 1988. Description of a new aeolid nudibranch (Mollusca: Opisthobranchia) belonging to the genus Phidiana. N. Z Journal of Zoology, 14(3): 409-417.

Scient. ed.: J.D. Ros 